\title{
Effect of compression ignition engine preheating on its performance under cold start conditions
}

ARTICLE INFO

Received: 10 August 2021

Revised: 15 September 2021

Accepted: 16 September 2021

Available online: 17 September 2021
This paper examines the effect of an external preheating system for an internal combustion engine on fuel consumption, $\mathrm{CO}_{2}$ emissions, and cabin temperature of a Euro4 vehicle. A $1 \mathrm{~kW}$ electric system powered by $220 \mathrm{~V}$ was installed in series in the cooling system of a vehicle with a compression-ignition engine of $2.5 \mathrm{dm}^{3}$ capacity. The tests were carried out in simulated urban driving conditions (distance of $4.2 \mathrm{~km}$ ), extra-urban driving conditions (distance of $17 \mathrm{~km}$ ), and during idling at cold-start temperatures ranging from $-10^{\circ} \mathrm{C}$ to $2^{\circ} \mathrm{C}$. Preheating the engine under simulated city conditions reduces fuel consumption by $2.64 \mathrm{dm}^{3} / 100 \mathrm{~km}$ and increases the supply air temperature immediately after engine start-up. Due to the preheater being powered from an external power grid, the cost per trip and total $\mathrm{CO}_{2}$ emissions are increased. Assuming renewable energy sources, $\mathrm{CO}_{2}$ emissions would be reduced the most for the stationary tests after engine preheating. In contrast, emissions would be reduced the least for extra-urban driving

Key words: internal combustion engine, engine warm-up, cold start, $\mathrm{CO}_{2}$ emissions, fuel consumption

This is an open access article under the CC BY license (http://creativecommons.org/licenses/BY/4.0/)

\section{Introduction}

The main task of an internal combustion engine cooling system is to transfer heat from the engine to the environment. Air-cooling systems are rarely used in today's vehicles; manufacturers usually choose liquid-cooling systems with a cooling medium. It is assumed that at least twothirds of the energy contained in the fuel is transferred to the environment as heat, among other things by the cooling system. On the basis of the heat released during the combustion process, the overall efficiency of the engine is determined. The highest efficiency of an automobile engine is estimated to be around $40 \%$, but that is also with a limited operating field [1]. Overall efficiency measures the ratio of the effective work done by the engine in one cycle to the heat extracted during that cycle from the fuel burned:

$$
\eta_{\mathrm{o}}=\frac{\mathrm{L}_{\mathrm{e}}}{\mathrm{Q}} \cdot 100 \%
$$

where: $\eta_{\mathrm{o}}$ - overall efficiency of the engine, $\mathrm{L}_{\mathrm{e}}$ - effective work (in one cycle) [J], Q - heat extracted from fuel [J].

It is estimated that [2] cooling losses from $26 \%$ to $32 \%$ of supplied heat - it is the energy carried by cooling fluid, it is taken from the engine elements exposed to very high temperatures (even 2000-3000 K) in order to protect them from heat damage.

At the point of friction the temperature must not exceed a certain limit value due to the thermal strength of the oil film. The limit temperature of engine oil is considered to be the piston temperature measured at the bottom of the channel of the first piston ring at $210^{\circ} \mathrm{C}$ [11].

The second basic function of the cooling system is to maintain the engine temperature within a certain range. The optimum and safe operating temperature for engines used in motor vehicles due to the acceptable heat loads on its components is usually between 85 and 95 degrees Celsius. This temperature is measured on the engine block. One of the reasons why the optimum operating temperature of the engine should be reached as soon as possible is due to constructional limitations. The materials used for the engine components, like all materials, are characterized by thermal expansion. This property changes volume and linear dimensions as a function of temperature. With decreasing temperature the volume and linear dimensions decrease, whereas with increasing temperature the volume and linear dimensions increase. Designers must take thermal expansion phenomenon into account when designing components such as pistons, cylinder head, engine block, etc. [3]. Adequate engine operating temperature is associated with lower power mechanical losses. This is why reaching an operating temperature of about 90 degrees Celsius in the shortest possible time is so important, because only then do the mechanical parts of the engine work together in the most optimal way. At lower temperatures, there can be too much clearance between the mechanically moving parts. In the long run, this can lead to faster wear or damage, generating very high repair costs, as well as temporarily taking the vehicle out of service until it is fully operational.

In order to increase the heating rate of the engine, the cooling system is split into multiple loops (two pumps and two coolers). In such a system, one circuit includes high temperature sources $\left(80-100^{\circ} \mathrm{C}\right)$ such as engine head, EGR cooler, and oil cooler and the other circuit includes low temperature sources $\left(35-45^{\circ} \mathrm{C}\right)$ such as $\mathrm{A} / \mathrm{C}$ condenser and second stage intercooler. This approach reduced $\mathrm{CO}_{2}$ emissions by $5 \mathrm{~g} \mathrm{CO}_{2} / \mathrm{km}$ and shortened the engine warm-up period by $25 \%$. The direct heating of the cooling liquid by means of exhaust gases was applied by Toyota in sparkignition engines to support the engine warm-up [16]. The efficiency of the classical cooling system can be increased by improving components such as the thermostat and coolant pump. Authors [12] proposed a comprehensive nonlinear control architecture for transient temperature tracking in multiple cooling circuits. In cooling system of experimental engine and transmission gear have been installed variable- 
position smart thermostat valve, two variable-speed electric pumps, and variable-speed electric radiator fan. In paper [13], the effectiveness of an electric pump was tested against a standard mechanical pump in an internal combustion engine cooling system. In paper [14], the effect of centrifugal pump geometry on its performance was analyzed in detail. They observed velocity fluctuations caused by the impeller-diffuser interactions both in the impeller and diffuser regions. In the article [15] 4 automotive cooling system pumps were tested for application in an aircraft compression-ignition combustion engine.

The main function of engine preheating systems is to bring the engine to optimum operating temperature in the shortest possible time and to prepare the engine for one of the operating phases called the working phase, even before it is started during cold weather. Engine pre-heating systems support the cooling system. Depending on the type, they are designed to positively influence the vehicle operation by reducing fuel consumption, reducing harmful exhaust gases to the atmosphere, improving the cold starting performance, reducing mechanical parts wear and tear and improving the comfort of the vehicle operation.

The concentration of pollutants in the exhaust gases is also variable depending on the operating temperature, or the temperature of the engine being cold-started. Internal combustion engine start-ups may be divided into two groups: "cold" start-ups and "hot" start-ups. This division depends on the values of engine and lubricating oil temperature occurring during the vehicle start-up operation [4]. "Hot" start-up of a compression-ignition engine occurs above the temperature of $60^{\circ} \mathrm{C}$ and when there is no necessity to use a device facilitating the start-up (flame plug, glow plug, etc.). Otherwise, we are dealing with "cold" starting. The decision on using the engine starting aid is made subjectively by the vehicle operator or automatically by the fuel injection control system. On the basis of own research (stationary tests on a 4-cylinder engine), the author of publication [5] proposed additionally to introduce the concept of socalled first daily start of an internal combustion engine. Such a start-up occurs after the vehicle has been parked for a minimum of $8 \mathrm{~h}$ overnight in an open space or indoors. The temperature of the first daily start-up of an internal combustion engine is equal to the temperature of the air surrounding the vehicle [6].

During the start-up of a compression-ignition engine, many negative phenomena are observed, which intensify during "cold" start-ups. The energetic properties of the engine starting system decrease and the starting resistant torque increases [7], [8]. Significant resistance to motion causes appearance of large values of current drawn by the starter in a short time. This influences the increase of: engine starting time, fuel consumption and emission. There is an increased emission of toxic components in the exhaust gases due to insufficient atomization and evaporation of the first fuel doses, evaporation of self-ignition, and incomplete and incomplete combustion of the fuel-rich fuel mixture [9].

The purpose of this study was to determine the effect of preheating on vehicle performance parameters such as fuel consumption and $\mathrm{CO}_{2}$ emissions and whether it would increase comfort in daily vehicle use. Chapter 2 presents the current use of engine preheating systems, Chapter 3 the research object and measurement systems, Chapter 4 the research methodology. Chapter 5 presents the results and analysis of the study. The work is concluded with a summary.

\section{Preheating systems}

The Figure 1 shows the classification of engine preheat systems. They can be divided into external (mounted as a separate engine system), internal (integrated with the engine), and static (being an external part of the engine bay).

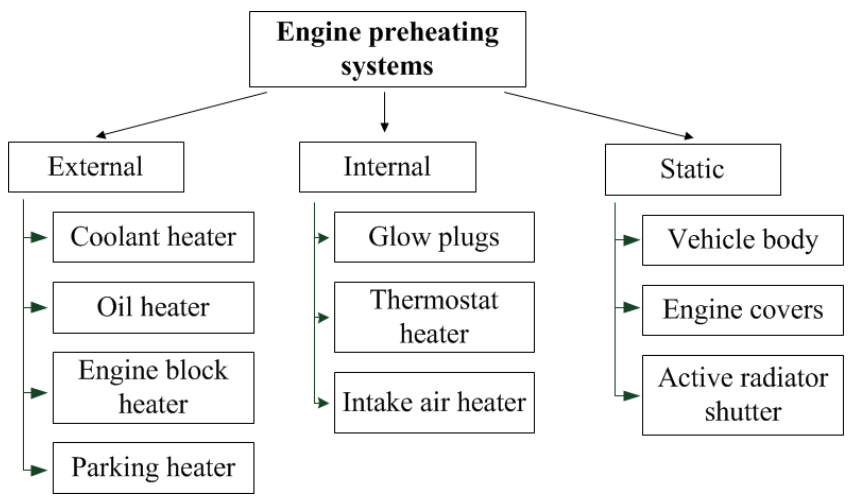

Fig. 1. Combustion engine coolant heat accumulators, pre-heating and temperature maintenance systems

External liquid heaters mounted in series or parallel in a walking circuit are equipped with an internal pump, an electric heating element and a thermostat. They can heat up the cooling system to a maximum of $50^{\circ} \mathrm{C}$. LF Bros coolant heaters for passenger vehicles are available in different power versions, with heaters from $1000 \mathrm{~W}$ up to $3000 \mathrm{~W}$. DEFA offers, apart from the duct heaters, also heaters mounted directly in the engine block. Heaters mounted in the engine block are only used in vehicles with engines that have a technological hole allowing the heater to be installed. Such holes are plugged with "brokas", in other words engine block plugs. After removing the blanking plug, the engine block heater can be placed in its place. Depending on the way of fixing, we divide engine block heaters into driven, screwed and bolted ones

Engine oil heaters are used to heat up engine oil while the engine is not running. Oil preheating before starting the engine allows to achieve in a shorter time the optimum operating temperature of oil and its better lubricating parameters just after starting the engine. There are systems in the form of a heater, a heating rod in the oil sump or a heater, a heating mat installed underneath the oil sump.

The purpose of a parking heater is to benefit the daily operation of the vehicle. Depending on the solution used, they allow for heating the vehicle cabin, the engine by heating the coolant or heating the cabin and engine simultaneously. In the combustion chamber of the parking heater, fuel supplied from the vehicle's factory fuel tank is burned. It is delivered to the combustion chamber by a fuel pump, which is part of the parking heater kit and operates independently of the fuel pump supplying the engine. The air required to burn the fuel is supplied to the combustion 
chamber by an air fan. During fuel combustion, the heat generated is extracted from the combustion chamber by a heat exchanger and transferred to the coolant. The circulation of the coolant through the system is forced by a circulating pump.

Internal systems that facilitate starting include glow plugs, intake air heaters and coolant heaters near the thermostat. The glow plugs have the function of heating the combustion chamber after starting. This prevents the excessive release of soot and harmful combustion compounds and increases the engine's operating comfort. The length of the reheating period depends on the engine temperature.

Intake air heaters are located in the intake manifold. The purpose of the warmer air is to make it easier to start a cold engine and to improve its operation after the engine has been started.

a)

b)

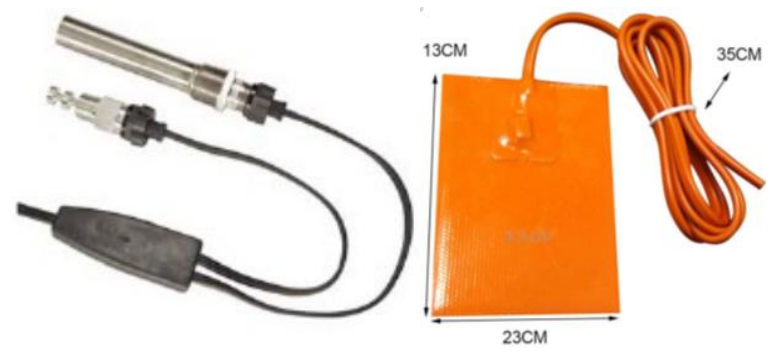

Fig. 2. Engine oil pre-heating system, a) heating rod, b) heating mat [10]

Intake air heaters are located in the intake manifold. The purpose of warmer air is to make it easier to start a cold engine and to improve the quality of operation after it has been started.

In automotive cooling systems, you can find thermostats that allow the coolant to reach temperatures higher than 90 degrees Celsius, the so-called phase thermostats. Phase thermostats are designed to maintain the temperature of the fluid at the most optimal level. The main difference in the principle of operation is that phase thermostats rely on information from the engine controller and the fluid temperature. When the engine load is increased, the ECU sends information to the electric heater, which heats heat extensible element in the thermostat, causing it to fully open as soon as the load is increased.

One way to increase engine warm-up is to use the active radiator shutter. When the cooling demand of the engine is low, the shutter automatically closes the air flow into the engine compartment which allows the engine to warm up faster due to less heat loss to the environment. In addition, body panels provide thermal protection by increasing engine warm-up while the vehicle is in motion and helping the engine to reach its optimum operating temperature. In addition, some vehicle models are equipped with engine guards mounted on the underside of the body. Their main role is to protect the engine from the water and dirt, but it also constitutes a thermal shield for the engine limiting the possibility of heat exchange of the engine compartment with the environment.

\section{Research object and measuring instruments}

The test vehicle used was a BMW 5 series, model E61, with a compression ignition engine with a displacement of $2497 \mathrm{~cm}^{3}, 130 \mathrm{~kW}$, complying with the Euro 4 standard and automatic transmission. The engine used in this vehicle is a four-stroke, six-cylinder in-line 24-valve engine. The powertrain used in the tested vehicle is powered by diesel fuel through a common rail system. According to the manufacturer's data, the tested vehicle has fuel consumption and $\mathrm{CO}_{2}$ emissions of:

- in urban test $-10.7 \mathrm{dm}^{3} / 100 \mathrm{~km}$,

- in extra urban test $-6.3 \mathrm{dm}^{3} / 100 \mathrm{~km}$,

- in combined test $-7.9 \mathrm{dm}^{3} / 100 \mathrm{~km}$,

- $\mathrm{CO}_{2}$ emission $-210 \mathrm{~g} / \mathrm{km}$.

The engine in the test vehicle has a liquid cooling system of volume $9.6 \mathrm{dm}^{3}$ and a lubrication system of volume $8.3 \mathrm{dm}^{3}$. Thus, there are about $7 \mathrm{~kg}$ of engine oil, $10 \mathrm{~kg}$ of coolant and $140 \mathrm{~kg}$ of engine metal parts to be heated.

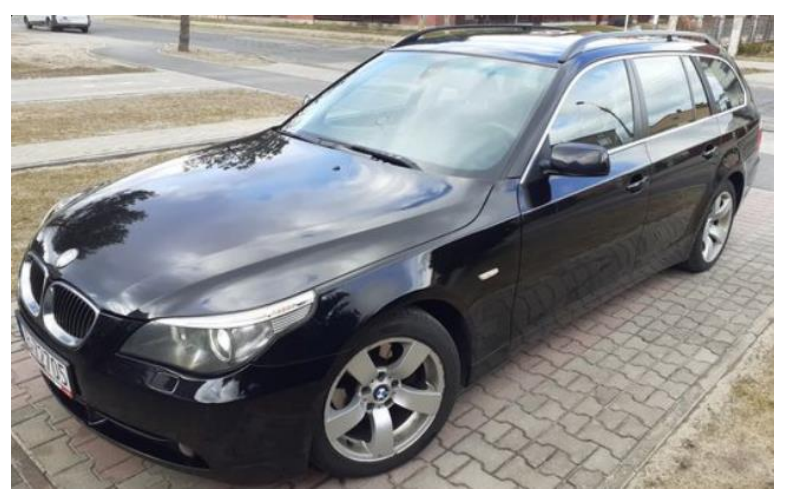

Fig. 3. Tested vehicle BMW E61

Installed in series in the vehicle's cooling system is a coolant heater LF Bros model D-12-8003 with a $1000 \mathrm{~W}$ heater, powered by $230 \mathrm{~V}$. The heat is transferred from the heater to the coolant. The circulation of the heated liquid in the system is forced by a pump, which is located inside the heater casing. LF Bros heater model D-12-8003 is equipped with an internal thermostat that turns off the heating element (heater) when the fluid temperature approaches $65-$ $70^{\circ} \mathrm{C}$ and restarts it when the temperature is around $60^{\circ} \mathrm{C}$. Note, however, that the heater shuts off at a given temperature reached by its internal thermostat. Due to heat loss, the motor itself reaches a lower temperature, depending on its capacity and design.

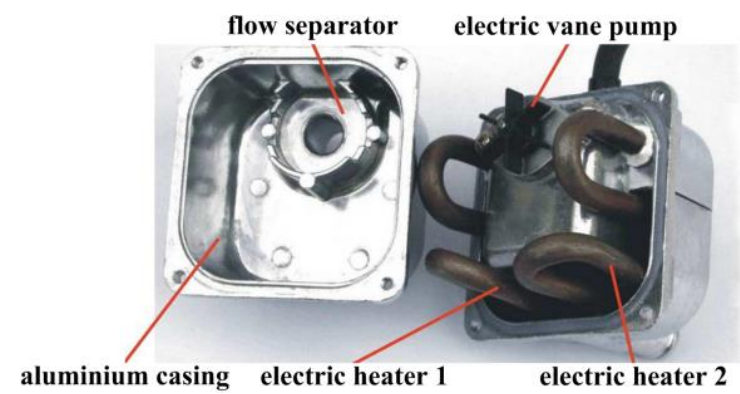

Fig. 4. Construction of LF Bros heater model D-12-8003 with $1000 \mathrm{~W}$ heater 
The following measuring instruments were used to test the effect of using the installed LF Bros engine preheating system on the performance parameters of the test vehicle:

- GreenBlue GB202 wattmeter,

- ELM327 iCar2 Vgate OBD2 INTERFACE,

- electronic thermometer,

- smartphone with the "Car Scanner" application.

A stationary test bench was made to determine the volumetric flow rate of the LF Bros model D-12-8003 engine preheat system pump.

A wattmeter was used to measure the amount of energy and consumed from the power grid to power the preheater under test. The ELM327 iCar2 Vgate OBD2 INTERFACE connected to the OBD-II socket and allowing communication with the vehicle was used to read out the engine and vehicle operating parameters. In order to display and read out the operating parameters, the ELM327 interface was connected via bluetooth to the free "Car Scanner" application installed on the Android device. During the tests, the application was used to read out data on coolant temperature and average fuel consumption. After finishing a given measurement and disconnecting the application from the interface, the data are automatically saved. The application enables reading of the saved data and its preview in the form of a chart.
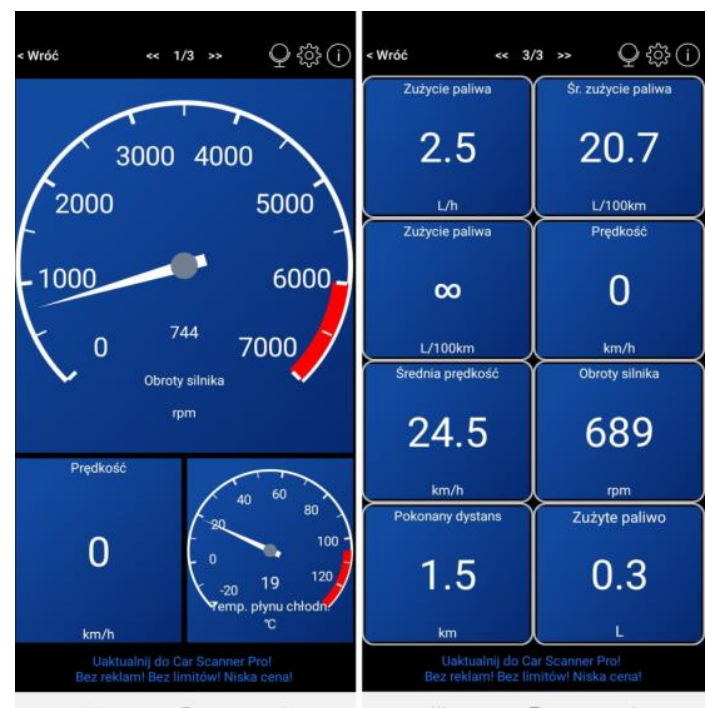

Fig. 5. Example of real-time preview of engine operating parameters using the "Car Scanner" application

\section{Methodology}

The effect of the engine preheating system on engine performance was investigated in 3 test scenarios:

- on a short route of $4.2 \mathrm{~km}$ ("urban"),

- over a long distance of $17 \mathrm{~km}$ ("extra urban"),

- with the engine switched off.

Each research scenario was repeated 5 times. The test vehicle was driven by the owner, who drives a short and long route on his daily work commute for several years. Driving characteristics show comparable driving values.

The first test track (city) was set entirely in a built-up area and the speed during its passage by the vehicle did not exceed $50 \mathrm{~km} / \mathrm{h}$. Moreover, it runs through very little traffic on residential roads and without traffic lights, which allowed to perform similar trips in terms of time and speed. In order to simulate the daily use of the vehicle, the test track had both left and right turns, gradients and sections to be driven at different speeds. Average travel time on urban route (distance $4.2 \mathrm{~km}$ ) was 8 minutes 38 seconds with average speed $28.19 \mathrm{~km} / \mathrm{h}$.

The second test track (the route) was designed to represent a mixed driving cycle, i.e. a combination of driving in built-up areas and outside built-up areas. However, the vast majority of the test track was outside built-up areas. Trial runs were made at late hours or on non-working days to minimize the impact of other traffic on the test results. The route was driven in accordance with applicable traffic regulations and speed limits. Average travel time on extra urban route (distance $17 \mathrm{~km}$ ) was 18 minutes 30 seconds with average speed $55.14 \mathrm{~km} / \mathrm{h}$.

The purpose of the stationary tests was to determine the amount of energy consumed for the tests with the engine preheating system and the amount of fuel consumed for the tests without the engine preheating system to achieve the required $\Delta \mathrm{t}\left[{ }^{\circ} \mathrm{C}\right]$ coolant temperature change. The vehicle engine was turned off during the preheater tests. The no heater tests were conducted at engine idle without the cabin heating on and without any other energy sources such as radios or heated seats. These factors have a direct impact on a vehicle's energy consumption, which translates into fuel burn rate and coolant temperature. During the tests, the preheating time was also measured both during engine operation and during tests with the LF Bros engine preheating system.

In addition, the temperature of the air blown into the cabin was measured using an electronic thermometer during the runs. The measuring element (thermocouple) was placed four centimeters deep in the center tunnel of the cabin air intake during the measurements. The display was placed in a prominent position. In order to obtain the most reliable results, during each measurement the value of the cabin heating potentiometer was set to $19^{\circ} \mathrm{C}$ and the vehicle was heated in "auto" mode. Measurements were performed both for tests, where LF Bros heater was used to preheat the engine and for tests without preheater.

The mean value of the mercury thermometer readings and the outside temperature indicated by the vehicle's onboard computer were used to determine the outside temperature. The fuel consumption is the arithmetic mean of the on-board computer readings and the data obtained from the "Car Scanner" application via OBDII.

To determine the amount of fuel consumed during idling tests, only the value indicated by OBD was used. To determine the external temperature, the mean value of the mercury thermometer and the internal temperature indicated by the vehicle's on-board computer were used.

\section{Test results and analysis}

The Figure 6 shows the temperature rise of the vehicle's engine coolant during testing with the electric heater alone. The vehicle's engine was turned off. The initial temperature of the engine and ambient was $6^{\circ} \mathrm{C}$. The coolant reached a temperature of $39^{\circ} \mathrm{C}$ after 60 minutes. Using the heater, we can heat the engine to a maximum of $46^{\circ} \mathrm{C}$ under the 
conditions presented. The preheat curve flattens out as the time increases, which means that there is a large heat loss to the environment. When the heater is used for more than 90 minutes, the losses to ambient air exceed the amount of energy released to the vehicle's engine. Under the same ambient conditions, it takes only 6 minutes to preheat the vehicle without the heater to $39^{\circ} \mathrm{C}$ using only the chemical energy of the fuel (vehicle engine idling).

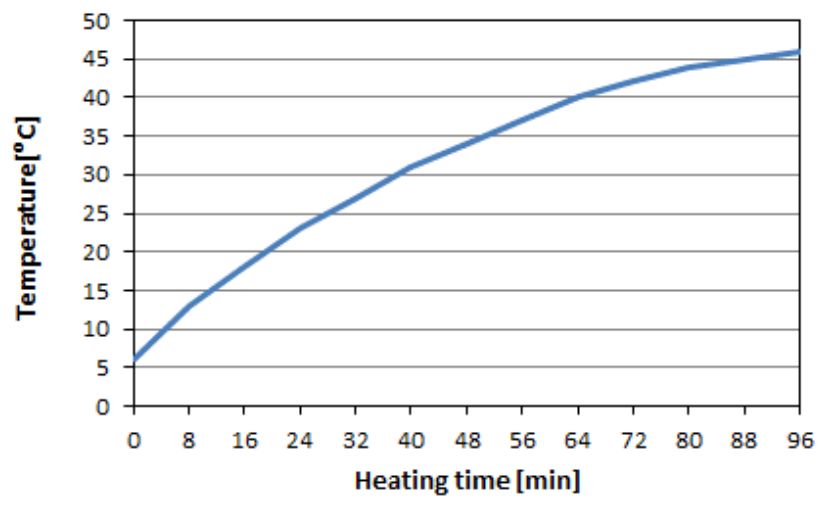

Fig. 6. Coolant temperature as a function of heater on time

The preheating of the engine allowed for an easier start and a more stable maintenance of the idle speed right after the start. Preheating the engine allows also to reduce the idling speed. The difference was definitely noticeable during the tests performed at outdoor temperatures below $0^{\circ} \mathrm{C}$. Figure 7 shows the values of the engine speed after start-up, during the test without engine preheating and during the test with engine preheating at an outside temperature of $-14^{\circ} \mathrm{C}$. The rotational speed of the cold engine was $1250 \mathrm{rpm}$ at the initial stage and then maintained at $1000 \mathrm{rpm}$. After preheating the engine, the engine speed was about $750 \mathrm{rpm}$, which allows the engine to consume less fuel just after starting, thus generating less pollution.

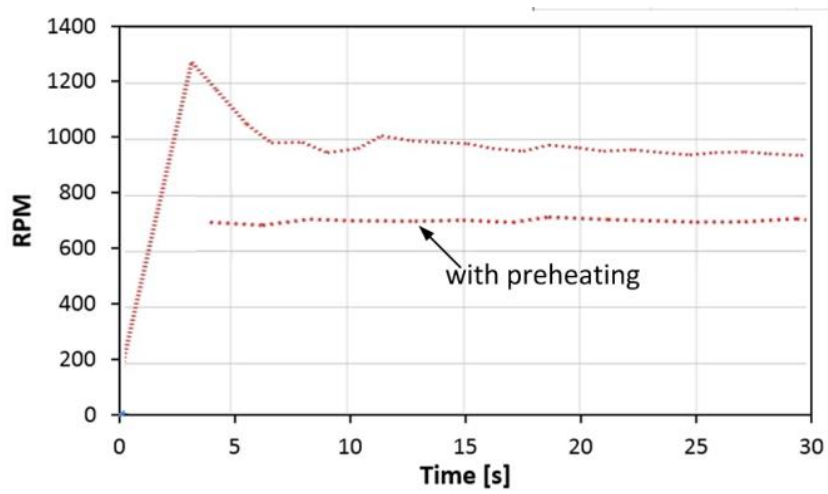

Fig. 7. Engine crankshaft speed at idle after starting with and without preheat system at $-14^{\circ} \mathrm{C}$

During all of the test runs performed on the test tracks, it can be seen that during runs with the engine preheating system, the vehicle coolant reached a higher temperature at the end of the run than during runs without the system. The Figure 8 shows the increase in coolant temperature for the sample runs without the engine preheat system and with the engine preheat system. The final coolant temperature dif- ference alone for the runs with and without the engine preheat system was not as large, compared to the initial temperature. This was directly related to the heating of the vehicle cabin. During each of the driving tests, to reflect daily vehicle operation, the cabin air intake was set to "auto" mode and the potentiometer was set to 19 degrees Celsius. Due to the low outside temperatures during the tests, the cabin space was heated, which involved taking heat in the heater from the coolant and transferring it to the interior of the vehicle.

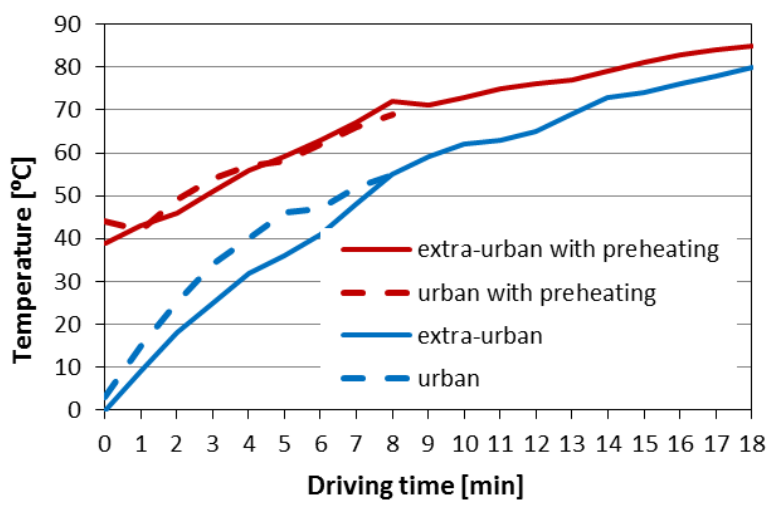

Fig. 8. Increase in engine temperature of the vehicle on the test track "urban" and "extra urban" as a function of driving time with and without engine preheating

Analyzing the graphs shown in Fig. 9 it can be seen that the supply air temperature for the first 8 minutes in the tests after engine preheating was significantly higher. This situation was repeated for the two test runs. Thus, travel comfort was definitely improved after engine preheating.

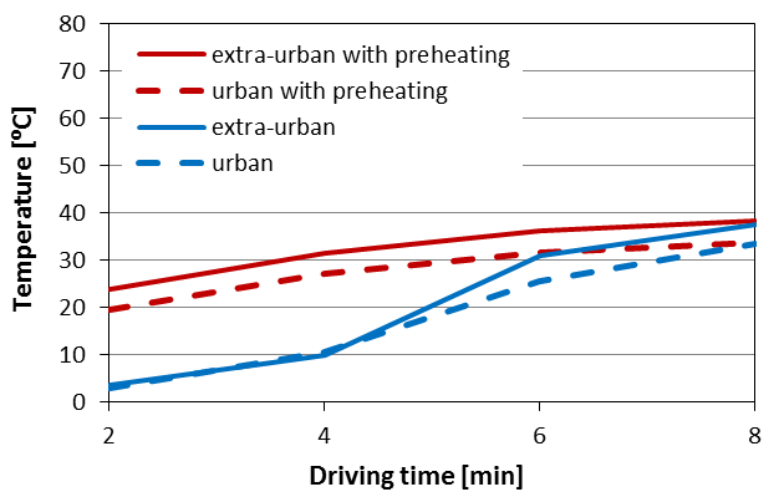

Fig. 9. Temperature increase of the supplied air to the vehicle cabin on the test track "urban" and "extra-urban" as a function of driving time with and without engine preheating

Engine preheating helps to reduce fuel consumption. The Figures 10 and 11 show the average fuel consumption during the "urban" and "extra urban" test under different ambient conditions. The basis for calculating the percentage reduction in fuel consumption was the fuel consumption without the heater. For both the first and second test runs, fuel consumption on average decreased by $8.99 \%$ and $1.95 \%$, respectively. Thus, it can be seen that the difference in fuel consumed decreases with the longer trip. This is directly related to the travel time and therefore the engine reaching a temperature closer to its optimum operating 
temperature. In the case of the second test track (extraurban), the difference in fuel consumption between runs with and without the heater was undoubtedly reduced by the fact that most of the test track was outside built-up areas. Driving outside built-up areas is characterized by less fluctuation of the engine load and therefore less fuel consumption. In addition, the fuel consumption of the two test tracks was related to the external temperature recorded during the tests. For the first track and the second track at the lowest temperature of $-9^{\circ} \mathrm{C}$ and $-12^{\circ} \mathrm{C}$, respectively, the highest combustion of the tested vehicle was observed for both runs with the preheating system without its use. For the urban run, the difference in fuel burned between the highest $\left(19.59 \mathrm{dm}^{3} / 100 \mathrm{~km}\right)$ and lowest $\left(17 \mathrm{dm}^{3} / 100 \mathrm{~km}\right)$ observed was $13.2 \%$ for the tests without the preheater and $6.5 \%$ for the tests with the preheater. During the "urban" tests, the difference in fuel burned between the highest $\left(12.3 \mathrm{dm}^{3} / 100 \mathrm{~km}\right)$ and lowest $\left(10.5 \mathrm{dm}^{3} / 100 \mathrm{~km}\right)$ observed results was $14.6 \%$ for the tests without the heater and $13.3 \%$ for the tests with the heater.

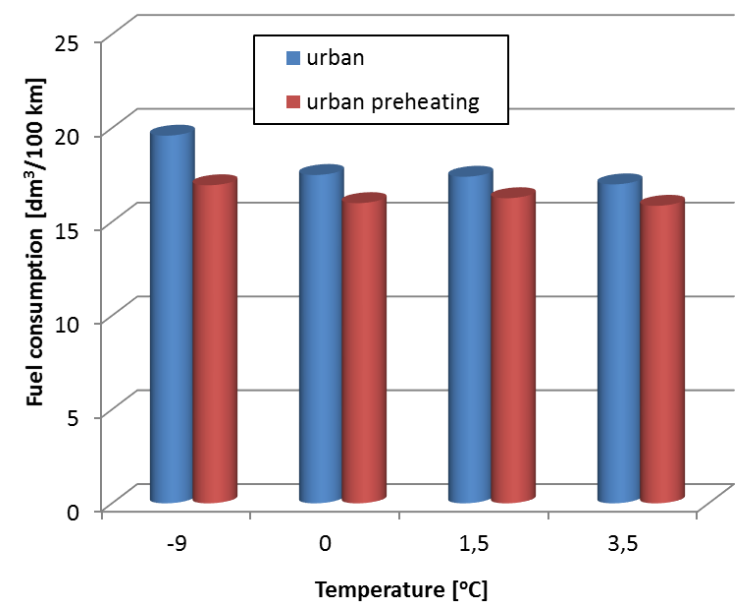

Fig. 10. Average fuel consumption on the ,urban” test at different ambient temperatures with and without engine preheating

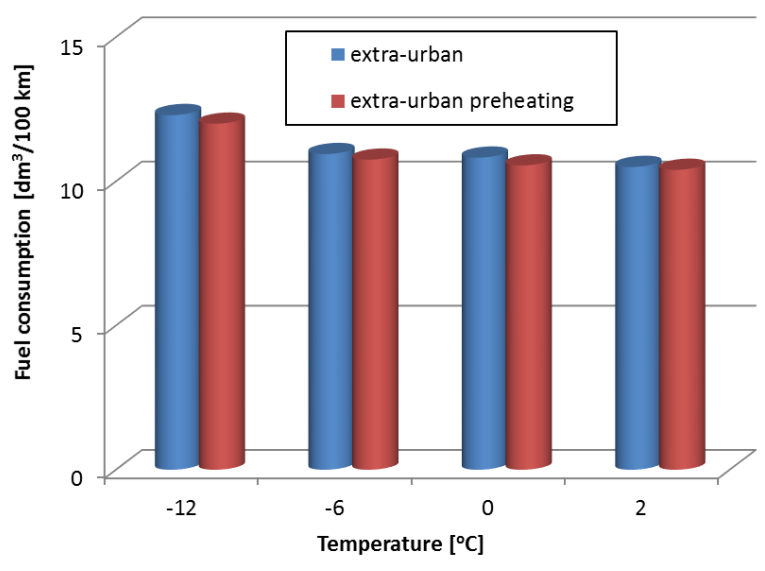

Fig. 11. Average fuel consumption on the „extra urban” test at different ambient temperatures with and without engine preheating

When analyzing the total cost of travel and the $\mathrm{CO}_{2}$ emissions of a vehicle using an electric engine preheater, it must be remembered that the unit draws its electricity from the grid. Thus, the cost of electricity consumed should be added to the price of the fuel consumed during the runs with the engine preheating system. The following values have been taken as a basis for the calculation of the total cost of the test runs: the average price of diesel fuel of 5.40 $\mathrm{PLN} / \mathrm{dm}^{3}$ and of electricity of $0.75 \mathrm{PLN} / \mathrm{kWh}$. During the tests the heater was run for 95 minutes.

The Table 1 shows the calculated difference in total cost of heating and driving $100 \mathrm{~km}$ during the tests with and without electric engine heating. The values shown are the difference in fuel cost consumed by the engine and the electricity cost consumed by the electric heater. For the idle tests, the engine preheating was more economical. The cost of fuel consumed to preheat the engine was greater than the cost of energy consumed to preheat the engine with the heater. The savings ranged from 11.5 PLN to a maximum of 16 PLN and were proportional to the decrease in ambient temperature. The lower the outside temperature, the more economically advantageous it is to use a heater only at idling speed. Table 1 shows that the total cost of electricity consumed by the heater and fuel burned increases the operating costs for both urban and extra-urban routes.

Table 1. The difference in the total cost of driving per test with an electric heater across different test scenarios and ambient temperatures

\begin{tabular}{|l|c|c|c|}
\hline \multirow{2}{*}{ Test scenario } & \multicolumn{3}{|c|}{ Temperature $\left[{ }^{\mathbf{0}} \mathbf{C}\right]$} \\
\cline { 2 - 4 } & $\mathbf{- 1 0}$ & $\mathbf{1 . 5}$ & $\mathbf{0}$ \\
\hline Idling [PLN] & -16 & -11.5 & -12.2 \\
\hline Urban [PLN/100 km] & +20.5 & +26 & +24.2 \\
\hline Extra-urban [PLN/100 km] & +6.1 & +7.1 & +6.4 \\
\hline
\end{tabular}

The cost of driving $100 \mathrm{~km}$ with a vehicle whose engine is heated using grid electricity is higher than if the engine is heated using the chemical energy of the fuel burned during both the urban and extra-urban test runs. Although the fuel consumption was lower after using the heater, the cost of the electricity used by the heater added to the fuel cost.

The total cost of trips using the heater on the urban gauge increased by an average of $21.8 \%$, while the extraurban gauge saw an average increase of $11.2 \%$ in the total cost of the trip. This cost decreases as the ambient temperature (initial engine temperature) decreases. Also, this cost is less for the extra-urban trials than for the urban trials. In order to make the cost of the urban and extra urban trials with and without the heater in the test vehicle the same, the engine preheat time would have to be reduced from 95 minutes to 19 minutes. Then the temperature would change by only $15^{\circ} \mathrm{C}$.

Another aspect discussed in the analysis is the amount of $\mathrm{CO}_{2}$ emitted in individual tests with and without engine preheating. Because the preheater is powered from the grid, the amount of $\mathrm{CO}_{2}$ generated during electricity generation must be added to the tests using the preheater in addition to the $\mathrm{CO}_{2}$ emitted from the fuel burned. The following data were adopted for the analysis:

- from burned $1 \mathrm{dm}^{3}$ of diesel fuel $2.3 \mathrm{~kg}$ of $\mathrm{CO}_{2}$ is generated [17],

- $0.719 \mathrm{~kg}$ of $\mathrm{CO}_{2}$ is emitted during the production of $1 \mathrm{kWh}$ of electricity [18]. 
The Table 2 shows the calculated difference in total $\mathrm{CO}_{2}$ emissions during the tests with and without heating the electric vehicle engine. In this case as in the case of the total cost of driving a route section with a preheated engine the $\mathrm{CO}_{2}$ emissions are higher in all cases. The reduced $\mathrm{CO}_{2}$ emissions resulting from the reduction in fuel consumption after the engine has been preheated do not compensate for the emissions resulting from the production of electricity consumed by the heater. For the "urban" test, on average, the total amount of $\mathrm{CO}_{2}$ emitted increased by $41 \%$, while the "extra urban" test saw a $22.6 \%$ increase in $\mathrm{CO}_{2}$ emissions for the heater tests. The highest $\mathrm{CO}_{2}$ emissions were recorded for low ambient temperatures, which resulted in higher fuel consumption.

Table 2. The difference in the total $\mathrm{CO}_{2}$ emissions per test with an electric heater powered from the electricity grid across different test scenarios and ambient temperatures

\begin{tabular}{|l|c|c|c|}
\hline \multirow{2}{*}{ Test scenario } & \multicolumn{3}{|c|}{ Temperature [ $\left.{ }^{\mathbf{0}} \mathbf{~}\right]$} \\
\cline { 2 - 4 } & $\mathbf{- 1 0}$ & $\mathbf{1 . 5}$ & $\mathbf{0}$ \\
\hline Idling $\left[\mathrm{kg} \mathrm{CO}_{2}\right]$ & +0.41 & +0.49 & +0.5 \\
\hline Urban $\left[\mathrm{kg} \mathrm{CO}_{2}\right]$ & +1.17 & +1.22 & +1.19 \\
\hline Extra-urban $\left[\mathrm{kg} \mathrm{CO}_{2}\right]$ & +1.23 & +1.33 & +1.23 \\
\hline
\end{tabular}

Considering the generation of electricity from renewable energy sources (RES) connected to the electricity grid, for example from a wind farm or a photovoltaic plant, we can expect a reduction in $\mathrm{CO}_{2}$ emissions to the atmosphere after using an electric heater. The Table 3 shows the calculated difference in total $\mathrm{CO}_{2}$ emissions during the tests with and without heating the electric vehicle engine.

In this case, after using RES to power the heater, the total $\mathrm{CO}_{2}$ emissions are lower in all cases. Under the assumption of obtaining energy from renewable energy sources, $\mathrm{CO}_{2}$ emissions would be reduced to the greatest extent for stationary tests after preheating the engine. In contrast, emissions would be reduced the least for the "extra urban" tests because the difference in fuel burned for the tests with and without the heater was less than for the "urban" tests.

Table 3. The difference in the total $\mathrm{CO}_{2}$ emissions per test with an electric heater powered by renewable energy sources across different test scenarios and ambient temperatures

\begin{tabular}{|l|c|c|c|}
\hline \multirow{2}{*}{ Test scenario } & \multicolumn{3}{|c|}{ Temperature [ ${ }^{\mathbf{C}} \mathbf{~}$} \\
\cline { 2 - 4 } & $\mathbf{- 1 0}$ & $\mathbf{1 . 5}$ & $\mathbf{0}$ \\
\hline Idling $\left[\mathrm{kg} \mathrm{CO}_{2}\right]$ & -0.94 & -0.85 & -0.88 \\
\hline Urban $\left[\mathrm{kg} \mathrm{CO}_{2}\right]$ & -0.25 & -0.11 & -0.15 \\
\hline Extra-urban $\left[\mathrm{kg} \mathrm{CO}_{2}\right]$ & -0.12 & -0.04 & -0.11 \\
\hline
\end{tabular}

\section{Summary}

The effect of preheating a compression ignition engine with a $1000 \mathrm{~W}$ electric preheater was analyzed. The preheater was run for 95 minutes at three ambient temperatures (coolant temperatures): $-10^{\circ} \mathrm{C}, 0^{\circ} \mathrm{C}, 2^{\circ} \mathrm{C}$. The device heats up the coolant in the system to maximum $47^{\circ} \mathrm{C}$.

The effect of an external preheating system for an internal combustion engine is as follows:

1. Enables faster heating of the engine in relation to the conventional drive.

2. Improves the comfort of vehicle operation by increasing the temperature of supplied air to the cabin to $22^{\circ} \mathrm{C}$.

3. the idling speed is reduced to the value of ca. $700 \mathrm{rpm}$ after starting the vehicle.

4. the vehicle start-up system and battery are less loaded during the engine start-up phase.

5. A reduction in fuel consumption and $\mathrm{CO}_{2}$ emissions was observed at both idle and simulated urban and extraurban driving conditions (up to $2.64 \mathrm{dm}^{3} / 100 \mathrm{~km}$ during urban trail and low ambient temperatures).

6. Due to the cost of powering the device from the electricity grid, the total cost of driving $100 \mathrm{~km}$ increased in the study vehicle.

The operating cost and $\mathrm{CO}_{2}$ emissions can be reduced by powering the vehicle's engine preheater from a grid connected renewable energy source.

\section{Nomenclature}

$\mathrm{CO}_{2}$ carbon dioxide

ECU electronic control unit

RES renewable energy sources

\section{Bibliography}

[1] KNEBA, Z. Studium problemów zarządzania ciepłem odprowadzanym silnika w samochodach osobowych Wydawnictwo Politechniki Gdańskiej. Gdańsk 2011.

[2] WAJAND, J.A., WAJAND, J.T. Tłokowe silniki spalinowe średnio- i szybkoobrotowe. Wydanie IV. Wydawnictwa Naukowo-Techniczne. Warszawa 2005.

[3] GÓRECKI, A. Technologia ogólna: podstawy technologii mechanicznych. WSiP. Warszawa 1984.

[4] PSZCZÓŁKOWSKI, J. Charakterystyki rozruchowe silników o zapłonie samoczynnym. Wyd. SEPP „Cogito”. 2004.

[5] DROŹDZIEL, P. O rozruchu silnika o zapłonie samoczynnym. Eksploatacja i niezawodność. 2007, 2(34), 51-59.

[6] DROŹDZIEL, P. Wybrane zagadnienia rozruchu samochodowego silnika o zapłonie samoczynnym. Polskie NaukowoTechniczne Towarzystwo Eksploatacyjne. Warszawa 2007.
[7] BUCK, W.H., LOHUIS, J.R. Lubricant effects on lowtemperature diesel engine cold starting. SAE Technical Paper 940097. 1994. https://doi.org/10.4271/940097

[8] DUVAL, H. Computer model of the lead/acid starter battery in automobiles. Journal of Power Sources. 1995, 53, 351357. https://doi.org/10.1016/0378-7753(94)02000-S

[9] GĘCA, M., BARAŃSKI, G., MAJCZAK, A. IC CI engine cold start-up facilitating systems tests. Logistyka. 2015, 3, 1452-1458.

[10] PAWO. www.pipewarm.com

[11] OGRODZKI, A. Technika cieplna w pojazdach. Wydawnictwo Komunikacji i Łaczności. Warszawa 1982.

[12] SALAH, M.H., MITCHELL, T.H., WAGNER, J.R. et al. A smart multiple-loop automotive cooling. IEEE/ASME Transactions on Mechatronics 2010, 15(1), 117-124. https://doi.org/10.1109/tmech.2009.2019723 
[13] WANG, X., LIANG, X., HAO, Z. et al. Comparison of electrical and mechanical water pump performance in internal combustion engine. International Journal of Vehicle Systems Modelling and Testing. 2015, 10(3), 205-223. https://doi.org/10.1504/IJVSMT.2015.070155

[14] FENG, J., LUO, X., BENRA, F.K. et al. Experimental investigation of velocity fluctuations in a radial diffuser pump. Journal of Hydrodynamics. 2015. 27(3), 332-339. https://doi.org/10.1155/2014/702318

[15] GĘCA, M.J., PIETRYKOWSKI, K., BARAŃSKI, G. Coolant pump for compression-ignition aircraft engine. Combustion Engines. 2019, 179(4), 52-57. https://doi.org/10.19206/CE-2019-408

Michał Jan Gęca, DEng. - Faculty of Mechanical Engineering, Lublin University of Technology.

e-mail: m.geca@pollub.pl
[16] KILMAN, G., HARADA, O., WTENABE, K. et al. The 1.8L engine of the new Toyota Prius. FISITA 2010. F2010A-043.

[17] KRÓL, E. Porównanie emisji zanieczyszczeń pojazdów z napędem elektrycznym i spalinowym. Napędy $i$ Sterowanie. 2017, 140-143.

[18] Wskaźniki emisyjności $\mathrm{CO}_{2}, \mathrm{SO}_{2}, \mathrm{NO}_{\mathrm{x}}, \mathrm{CO}$ i pyłu całkowitego dla energii elektrycznej na podstawie informacji zawartych w Krajowej bazie o emisjach gazów cieplarnianych i innych substancji za 2019 rok. Krajowy Ośrodek Bilansowania $i$ Zarzadzania Emisjami. Warszawa 2020. https://www.kobize.pl/

Prof. Gojmir Radica, DEng. - Faculty of Electrica Engineering, Mechanical Engineering and Naval Architecture, University of Split, Croatia. e-mail: gojmir.radica@fesb.hr 